\title{
Epidermal Growth Factor Versus Conventional Wound Dressings In Treatment Of Diabetic Ulcers- A Comparative Study
}

\author{
Dr. Vimal Ramachandran ${ }^{1}$,Dr. B Ramdas Rai ${ }^{2}$,Dr. B Preetham Rai ${ }^{3}$ \\ ${ }^{I}$ (Resident, Department Of General Surgery, K.S.Hegde Medical Academy/ Nitte University, Mangalore, \\ Karnataka, India)

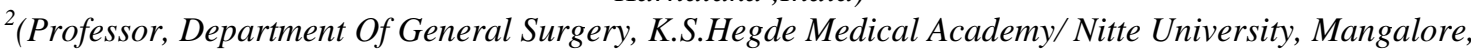 \\ Karnataka ,India) \\ ${ }_{3}^{3}$ (Professor, Department Of General Surgery, Kanachur Institute Of Medical Science And Research, \\ Mangalore, Karnataka ,India)
}

\begin{abstract}
With the advent of various advances in medical technology in twenty first century, many techniques have been tried to heal chronic leg ulcers. Although there exists no ideal wound dressing in the management of chronic wounds especially diabetic ulcers, several methods of wound dressing is being used and still evaluated. Hence we conducted the following study to evaluate the efficacy of Epidermal Growth Factor over conventional dressings in the healing of diabetic ulcers.

The study was a prospective case control comparative Study titled "Epidermal growth factor versus conventional wound dressings in treatment of diabetic ulcers- A comparative study" done in the department of General Surgery, K S Hegde Medical Academy, during the time period August 2014 to August 2016, on cases of diabetic ulcers who visited the OPD and IPD of K.S. Hegde Hospital, Mangalore. Study was conducted on 40 consenting patients who met the predefined criteria, divided into 2 groups of 20 patients with the Epidermal growth factor dressing and 20 patients with conventional dressing.

The data was collected in a proforma and the details transferred to a master chart and the results were analyzed.

Statistical Analysis was done using SPSS software version 23.0. In our study we used paired t test to check the level of statistical significance. A ' $p$ ' value less than $0.05(p<0.05)$ is considered significant.

In our study a total of 40cases, of which 20 with conventional dressings and 20 with EGF dressings were studied. There was no significant difference in the demographic factors or the duration and size of the ulcer between the two groups of study. In our study males predominated in the study population. Acute wounds of less than I month duration were mostly studied. There was increased rate of granulation tissue formation and the size of the ulcer decreased drastically with EGF therapy

In our study we concluded that Epidermal Growth Factor definitely has an edge over the conventional dressings in the healing of diabetic ulcers in terms of granulation tissue formation, and healing of the ulcer especially in diabetic wounds of less than one month duration.
\end{abstract}

Keywords: Epidermal Growth Factor, Conventional dressings, Diabetic ulcers ,Wound healing

\section{Introduction}

Diabetes is considered as the health crisis of the $21^{\text {st }}$ century. Approximately $15 \%$ of all patients with diabetes develop diabetic ulcers. Due to the associated diabetic neuropathy these ulcers are left unattended and are often followed by amputations in the later stages. Due to the increased glucose levels in the tissues, these diabetic ulcers are mostly infected. In recent years the technology of dressing has developed significantly, and several new products which reflect greater knowledge of tissue repair physiology have been produced and successfully used for the management of various types of chronic ulcers. However there is limited information to guide treatment of diabetic ulcers. ${ }^{1}$

Growth factors play a very important part in the process of wound healing. Epidermal Growth Factor was discovered by an American Biochemist Stanley Cohen in 1986, for which he won Nobel Prize in physiology and medicine.$^{2}$ Epidermal growth factor is a type of growth factor which is synthesized by the cells of the hematopoietic system namely the megakaryocytes, macrophages monocytes and keratinocytes as shown by Loot, Kenter et al. 2002. It act by regulating the proliferation, migration and differentiation of cells by a mechanism of binding to receptor kinases on target cells ${ }^{3}$

Epidermal growth factor induce cellular proliferation through the EGF receptor, which has a tyrosine kinase cytoplasmic domain, a single trans membrane domain, \& an extra cellular domain involved in EGF binding \& receptor dimerization. The proliferative effects of EGF are signaled through several pathways. EGF promotes mitogenesis of fibroblasts, endothelial cells and keratinocytes.

The functions of epidermal growth factor are ${ }^{4-7}$ 
- Helps in keratinocyte migration,

- Helps in fibroblast function

- Helps in formation of granulation tissue.

- $\quad$ participates in dermal wound healing by

○ stimulation, proliferation, and migration of keratinocyte

- stimulation and proliferation of endothelial cells, and stimulation and proliferation of fibroblast

- Facilitating dermal regeneration.

- $\quad \mathrm{EGF}$ is one of the key signaling molecules in stimulating epithelial cell motility, making it a required factor for re-epithelialization

- $\quad$ EGF is a major stimulator of fibroblast migration and wound contraction

Studies have proved that EGF is more useful in acute than in chronic wounds as this factor is readily degraded in the chronic wound milieu. There are limited studies in Indian subcontinent and no major studies in south Indian population conducted so far. This study is intended to show the efficacy of epidermal growth factor over conventional dressings in the healing of diabetic ulcers.

\section{II.Aims And Objectives Of The Study}

The aim of the present study was to study the efficacy of epidermal growth factor over conventional dressings in the healing of diabetic ulcers.

\section{Materials And Methods}

The study was a prospective case control comparative Study conducted in the Department of General Surgery, K. S Hegde Hospital during the time period August 2014 to August 2016.

The study was done on 40 patients

- 20 patients with epidermal growth factor dressings

- 20 patients with conventional wound dressings

The dressing method was decided by the patient after explaining everything about both the dressings.

Inclusion Criteria

- $\quad$ Patients aged 20-80 years of age.

- Patients with diabetes whose blood sugar level are controlled by oral hypoglycaemic drugs or insulin.

- Ulcer size 3-10 cm

\section{Exclusion Criteria}

- Patients with any active systemic infections.

- Ulcer size more than $10 \mathrm{~cm}$.

- Immuno compromised individuals.

- Any chronic pathology or systemic therapy which would obstruct the healing process.

- $\quad$ Patients with $\geq$ Grade III Wagner classification of diabetic ulcer

\section{Procedure}

Any dressings from the wound was removed and discarded. Wound irrigation was done with normal saline. Surgical debridement was done and adequate hemostasis achieved, following which

- 20 patients received topical Epidermal growth factor dressing.

- 20 patients received conventional wound dressing

The size of the ulcer measured in day 1 , day15 and one month

\section{Gender distribution}

\section{IV.Results And Observations}

Males predominated in our study. However between the two groups there was no statistical difference in the gender 


\begin{tabular}{|c|c|c|c|c|}
\hline & & \multicolumn{2}{|c|}{ Group } & \multirow[b]{2}{*}{ Total } \\
\hline & & Cases & Controls & \\
\hline \multirow[t]{4}{*}{ SEX } & $\bar{F}$ & 2 & 2 & 4 \\
\hline & & $10.0 \%$ & $10.0 \%$ & $10.0 \%$ \\
\hline & $M$ & 18 & 18 & 36 \\
\hline & & $90.0 \%$ & $90.0 \%$ & $90.0 \%$ \\
\hline \multirow{2}{*}{\multicolumn{2}{|c|}{ Total }} & 20 & 20 & 40 \\
\hline & & $100.0 \%$ & $100.0 \%$ & $100.0 \%$ \\
\hline
\end{tabular}

Table 1 - Gender Distribution within group

\section{Age Distribution}

Graph 1: Gender distribution within group

In our study the mean age in the case group was 57.60 years and in control group was 58.37 years.

Between the two groups there was no statistical difference in the age

\begin{tabular}{|ll|r|r|r|}
\hline & & \multicolumn{2}{|c|}{ Group } & \multirow{2}{*}{} \\
\cline { 3 - 4 } & & \multicolumn{1}{|c|}{ Cases } & Controls & \multicolumn{1}{c|}{ Total } \\
\hline AGE & 50 and below & 6 & 6 & 12 \\
& & $30.0 \%$ & $30.0 \%$ & $30.0 \%$ \\
\cline { 2 - 4 } & $51-60$ & 5 & 7 & 12 \\
& & $25.0 \%$ & $35.0 \%$ & $30.0 \%$ \\
\hline $61-70$ & 6 & 6 & 12 \\
& & $30.0 \%$ & $30.0 \%$ & $30.0 \%$ \\
\cline { 2 - 4 } & Above 70 & 3 & 1 & 4 \\
& & $15.0 \%$ & $5.0 \%$ & $10.0 \%$ \\
\hline Total & 20 & 20 & 40 \\
& & $100.0 \%$ & $100.0 \%$ & $100.0 \%$ \\
\hline
\end{tabular}

Fishers exact test $\mathrm{p}=.721$, NS

Table 2: Age Distribution within group

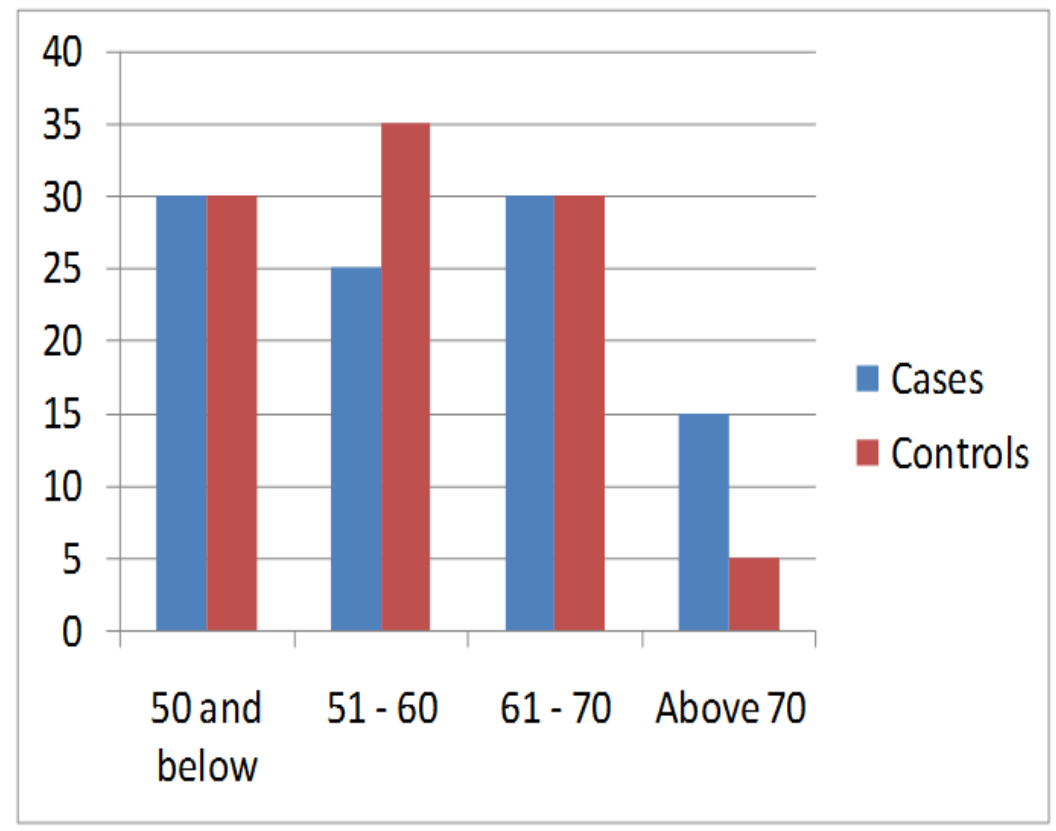

Graph 2: Age distribution percentage within group

\section{Duration of the ulcer}

In our study, there was no statistical difference in the duration of ulcer between the two groups. Most of the ulcers were of less than one month duration in both the groups 


\begin{tabular}{|c|c|c|c|c|}
\hline & & \multicolumn{2}{|c|}{ Group } & \multirow[b]{2}{*}{ Total } \\
\hline & & Cases & Controls & \\
\hline \multirow{6}{*}{$\begin{array}{l}\text { DURATION } \\
\text { OFULCER }\end{array}$} & Below 1month & 11 & 12 & 23 \\
\hline & & $55.0 \%$ & $60.0 \%$ & $57.5 \%$ \\
\hline & 1 - 2months & 7 & 7 & 14 \\
\hline & & $35.0 \%$ & $35.0 \%$ & $35.0 \%$ \\
\hline & Above 2 months & 2 & 1 & 3 \\
\hline & & $10.0 \%$ & $5.0 \%$ & $7.5 \%$ \\
\hline \multirow{2}{*}{\multicolumn{2}{|c|}{ Total }} & 20 & 20 & 40 \\
\hline & & $100.0 \%$ & $100.0 \%$ & $100.0 \%$ \\
\hline
\end{tabular}

Figure 3: Duration of the ulcer

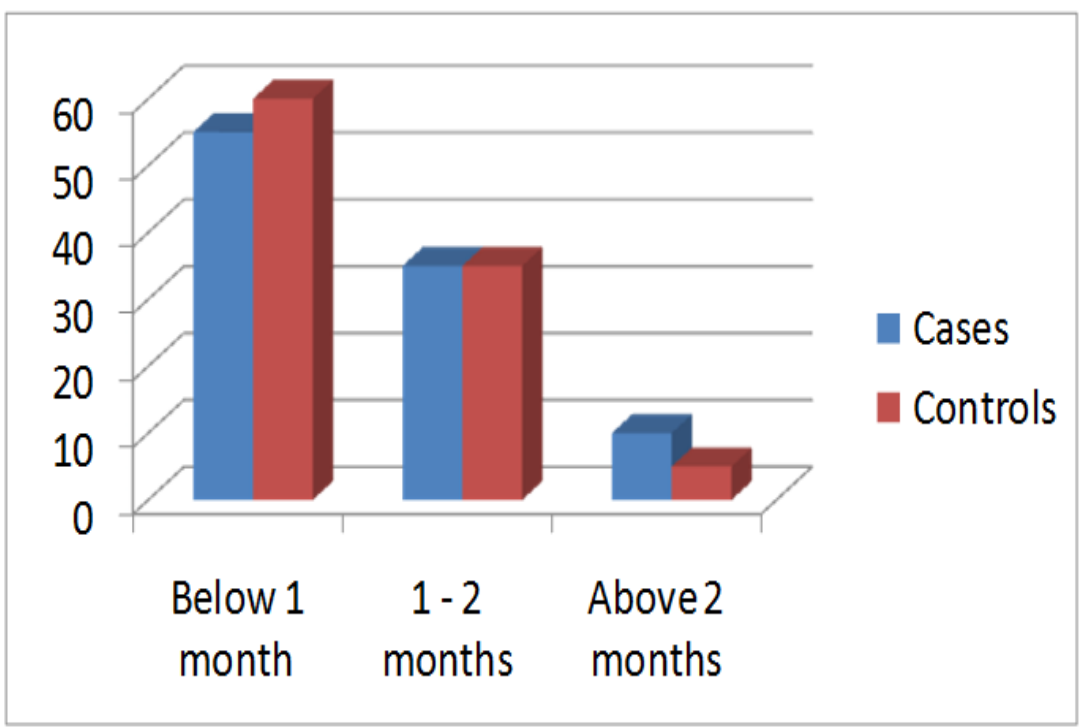

Graph 3: Duration of the ulcer (Group Cross tabulation \% within Group)

\section{Comparison of change in size of the ulcer within the group}

There is significant change in the size of ulcer both in the control group and the case group between Day 1 to 15 days, Day 15 to 1 month and between day 1 to 1 month

\begin{tabular}{|c|c|c|c|c|c|c|c|}
\hline \multirow[b]{3}{*}{ Group } & & \multicolumn{4}{|c|}{ Paired Differences } & \multirow{3}{*}{$\begin{array}{l}\text { Bonferron } \\
\text { ip value }\end{array}$} & \\
\hline & & \multirow[b]{2}{*}{ Mean } & \multirow[b]{2}{*}{ Std. Deviation } & \multicolumn{2}{|c|}{$\begin{array}{l}95 \% \text { Confidence } \\
\text { Interval of the } \\
\text { Difference }\end{array}$} & & \\
\hline & & & & Lower & Upper & & \\
\hline \multirow[t]{3}{*}{ Cases } & DAY1-DAY15 & 2.90970 & 1.95287 & 1.99573 & 3.82367 & .000 & HS \\
\hline & DAY 1 - 1 MONTH & 4.7692 & 2.5014 & 3.5985 & 5.9398 & .000 & HS \\
\hline & DAY 15 - 1 MONTH & 1.85945 & 1.58945 & 1.11556 & 2.60334 & .000 & HS \\
\hline \multirow[t]{3}{*}{ Controls } & DAY 1-DAY15 & 1.43050 & 1.47412 & .74059 & 2.12041 & .000 & HS \\
\hline & DAY 1-1 MONTH & 2.4690 & 2.2078 & 1.4357 & 3.5023 & .000 & HS \\
\hline & DAY 15 - 1 MONTH & 1.03850 & 1.01421 & .56384 & 1.51316 & .000 & HS \\
\hline
\end{tabular}

Table 4: Comparison of change in size of the ulcer within the group

\section{Comparison of change between the groups over the duration}

Between the two groups there was statistical difference in the change in the ulcer size following treatment with EGF. It was noticed that the decrease in ulcer size was more evident in the first 15 days when compared to the next 15 days. 


\begin{tabular}{|c|c|c|c|c|c|c|c|c|}
\hline & \multirow[b]{3}{*}{ Group } & \multicolumn{4}{|c|}{ Paired Differences } & \multirow[b]{3}{*}{$t$} & \multirow[b]{3}{*}{$p$ value } & \\
\hline & & \multirow[b]{2}{*}{ Mean } & \multirow[b]{2}{*}{ Std. Deviation } & \multicolumn{2}{|c|}{$\begin{array}{l}95 \% \text { Confidence } \\
\text { Interval of the } \\
\text { Difference }\end{array}$} & & & \\
\hline & & & & Lower & Upper & & & \\
\hline \multirow[t]{2}{*}{ Pair 1 DAY1-DAY15 } & Cases & 2.90970 & 1.95287 & 1.99573 & 3.82367 & \multirow[t]{2}{*}{2.698} & \multirow[t]{2}{*}{.010} & \multirow[t]{2}{*}{ sig } \\
\hline & Controls & 1.43050 & 1.47412 & .74059 & 2.12041 & & & \\
\hline \multirow[t]{2}{*}{ Pair 2 DAY1-1MONTH } & Cases & 4.7692 & 2.5014 & 3.5985 & 5.9398 & \multirow[t]{2}{*}{3.053} & \multirow[t]{2}{*}{.004} & \multirow[t]{2}{*}{ HS } \\
\hline & Controls & 2.4690 & 2.2078 & 1.4357 & 3.5023 & & & \\
\hline \multirow[t]{2}{*}{ Pair 3 DAY 15 - 1 MONTH } & Cases & 1.85945 & 1.58945 & 1.11556 & 2.60334 & \multirow[t]{2}{*}{2.051} & \multirow[t]{2}{*}{.046} & \multirow[t]{2}{*}{ sig } \\
\hline & Controls & 1.03850 & 1.01421 & .56384 & 1.51316 & & & \\
\hline
\end{tabular}

Table 5: Comparison of change in size of the ulcer between the groups

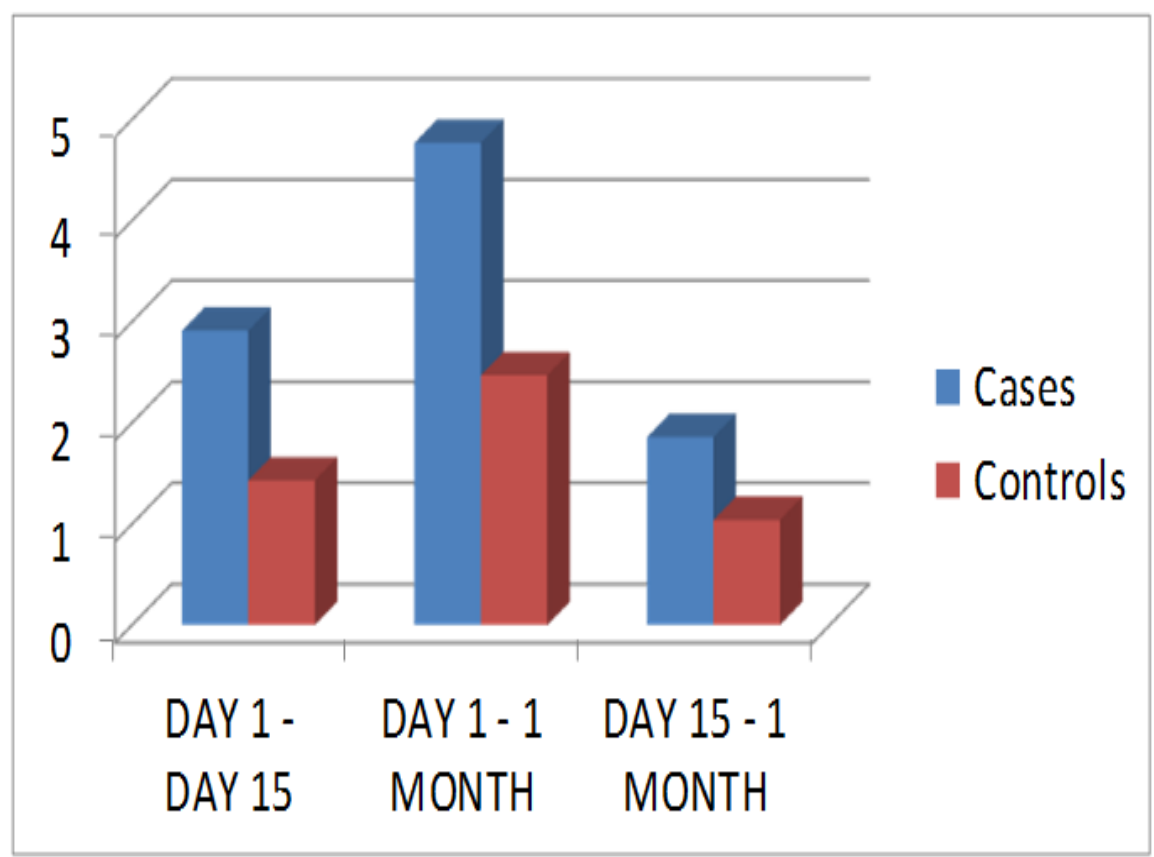

Graph 4: Comparison of change in size of the ulcer between the groups

\section{Discussion}

Based on the analysis of the results and comparing with other similar studies, following inferences can be drawn:

- We found that in our study the size of the ulcer significantly decreased with EGF

- It was noticed that the decrease in ulcer size was more evident in the first 15 days when compared to the next 15 days.

- During this time the ulcer size has reduced more than $50 \%$ as compared to the conventional group in which the decrease in size was less than $25 \%$ for most ulcers

- In our study we also noted that as compared to the first day, on the $30^{\text {th }}$ day the ulcer healing in terms of size ranged from 54-81.5\% in the EGF group as compared to the conventional group in which the decrease in size ranged from $34-47 \%$

- In our study we also found that the patient satisfaction and co-operation was much better in the EGF group as compared to the conventional group in most ulcers. The possible reason attributed to this is the lesser need of surgical debridement due to lesser slough.

- The amount of pain experienced was lesser in the study group as compared to the conventional group in most ulcers

- The therapeutic achievements of EGF are by EGF receptor stimulation and cyto-protection and proliferation effects. 
- Sanjeev singla et al showed $80 \%$ of patients showed complete response to EGF application, in our study group $50 \%$ reduction in size of the ulcer was noted at the end of one month. However their study period was two months ${ }^{8}$

- Our study showed a positive effect on wound healing and granulation issue formation this result is similar to the studies by Hoon et al, Yera- Alos IB et al, Fernández-Montequín, Tuyet HL et al, Man Wo Tsang et al , Ramakrishna et al, Huo Qiu et al, Dogan, Demirer et al, Yang s et al, Afshari M et al, Richard et al, Doerler et al, and Khanbanha et al $^{9-21}$

- Breeden et al in their study showed that topical EGF has moderately positive effect on wound healing and it can enhance burn wound healing by 1-4 days. ${ }^{22}$

- Studies by S.P. Bennett et al and Crossland et al. found that EGF did not tend to demonstrably accelerate the healing process. ${ }^{23,24}$

\section{Conclusion}

In our study we have concluded that Epidermal Growth Factor definitely has an edge over conventional dressings in the healing of diabetic ulcers in terms of granulation tissue formation, and healing of the ulcer especially in diabetic wounds of duration less than a month

\section{Limitations}

The limitations of the study are

- As ours is a tertiary care centre, the cases don't represent the actual burden and type in the population at study

- The small sample size in comparison to the disease burden in the society

- The short duration of study as compared to the chronicity of the disease

\section{References}

[1]. Hardwicke J, Schmaljohann D, Boyce D, Thomas D. Epidermal growth factor therapy and wound healing-past, present and future perspectives. The Surgeon. 2008 Jun 30;6(3):172-7.

[2]. Carpenter G, Cohen S. Epidermal growth factor. Annual review of biochemistry. 1979 Jul;48(1):193-216

[3]. Loots MA, Kenter SB, Au FL, Van Galen WJ, Middelkoop E, Bos JD, Mekkes JR. Fibroblasts derived from chronic diabetic ulcers differ in their response to stimulation with EGF, IGF-I, bFGF and PDGF-AB compared to controls. European journal of cell biology. 2002 Mar 31;81(3):153-60.

[4]. Berlanga-Acosta J. Gavilondo-Cowley J. Lopez-Saura P. Gonzalez-Lopez T. Castro-Santana MD. Lopez-Mola E, et al. Epidermal growth factor in clinical practice - a review of its biological actions, clinical indications and safety implications. Int Wound J.2009;6:331.

[5]. Kondo S. Kuroyanagi Y. Development of a wound dressing composed of hyaluronic acid and collagen sponge with epidermal growth factor. J BiomaterSciPolym Ed.2012;23:629.

[6]. Werner S. Grose R. Regulation of wound healing by growth factors and cytokines. Physiol Rev. 2003;83:835.

[7]. Brown GL, Curtsinger L, Brightwell JR, Ackerman DM, Tobin GR, Polk HC Jr, GeorgeNascimento C, Valenzuela P and Schultz GS (1986). Enhancement of epidermal regeneration by biosynthetic epidermal growth factor. The Journal of Experimental Medicine 163 1319-1324.

[8]. Sanjeevsingla, SudeepSingla, Arun Kumar, MamtaSingla. Role Of Epidermal Growth Factor In Healing Of Diabetic Foot. Indian JSurg 2012; 74 (6):451-455

[9]. Hoon, JoonPio, Jung, Heun Don, Kim, Yun Wha. Recombinant human epidermal growth factor to enhance diabetic foot ulcers. Annals Of Plastic Surgery: 2006;56(4):394-398

[10]. Isis B Yera-Alos, Liuba Alonso-Carbonell, Carmen M Valenzuela-Silva Angela D Tuero-Iglesias, Martha MoreiraMartínez, Ivonne Marrero-Rodríguez et al. Active post-marketing surveillance of the intralesional administration of human recombinant epidermal growth factor in diabetic foot ulcers.BMC PharmacolToxicol.2013; 14: 44.

[11]. Valenzuela-Silva CM1, Tuero-Iglesias ÁD, García-Iglesias E, González-Díaz O, Del Río-Martín A, YeraAlos IB, FernándezMontequín JI, López-Saura PA. Granulation response and partial wound closure predict healing in clinical trials on advanced diabetes foot ulcers treated with recombinant human epidermal growth factor. Diabetes Care. 2013;36(2):210-5

[12]. Fernández-Montequín JI, Valenzuela-Silva CM, Díaz OG, Savigne W, Sancho-Soutelo N, Rivero-Fernández F, Sánchez-Penton P, et al. Intra-lesional injections of recombinant human epidermal growth factor promote granulation and healing in advanced diabetic foot ulcers: multicenter, randomised, placebo-controlled, double-blind study. Int Wound J. 2009 Dec;6(6):432-43

[13]. Fernández-Montequín JI, Infante-Cristiá E, Valenzuela-Silva C, Franco-Pérez N, Savigne-Gutierrez W, Artaza-Sanz H et al. Intralesional injections of Citoprot-P (recombinant human epidermal growth factor) in advanced diabetic foot ulcers with risk of amputation. Int Wound J. 2007 Dec;4(4):333-43.

[14]. Fernández-Montequín JI, Betancourt BY, Leyva-Gonzalez G, Mola EL, Galán-Naranjo K, Ramírez-Navas M et al. Intralesional administration of epidermal growth factor-based formulation (Heberprot-P) in chronic diabetic foot ulcer: treatment up to complete wound closure.Int Wound J. 2009 Feb;6(1):67-72.

[15]. Tuyet HL, Nguyen Quynh TT, Vo Hoang Minh H, ThiBich DN, Do Dinh T, Le Tan D, Van HL, Le Huy T, Doan Huu H, Tran Trong TN. The efficacy and safety of epidermal growth factor in treatment of diabetic foot ulcers: the preliminary results. Int Wound J. 2009 Apr;6(2):159-66

[16]. Tsang MW, Wong WK, Hung CS, Lai KM, Tang W, Cheung EY, Kam G, Leung L, Chan CW, Chu CM, Lam EK. Human epidermal growth factor enhances healing of diabetic foot ulcers. Diabetes Care. 2003 Jun;26(6):1856-61

[17]. Ramakrishna and Vaidya Dressing With Topical Application Of Epidermal Growth Factor Gel In The Management Of Chronic Wounds: A Prospective Study CIBTech Journal of Surgery 2014 Vol. 3 (3) September-December, pp. 29-32. 
[18]. Huo Y, Qiu WY, Pan Q, Yao YF, Xing K, Lou MF. Reactive oxygen species (ROS) are essential mediators in epidermal growth factor (EGF)-stimulated corneal epithelial cell proliferation, adhesion, migration, and wound healing. Experimental eye research. 2009 Dec 31;89(6):876-86.

[19]. Dogan S, Demirer S, Kepenekci I, Erkek B, Kiziltay A, Hasirci N, Müftüoğlu S, Nazikoğlu A, Renda N, Dincer UD, Elhan A. Epidermal growth factor-containing wound closure enhances wound healing in non-diabetic and diabetic rats. International wound journal. 2009 Apr 1;6(2):107-15

[20]. Yang S, Geng Z, Ma K, Sun X, Fu X. Efficacy of Topical Recombinant Human Epidermal Growth Factor for Treatment of Diabetic Foot Ulcer A Systematic Review and Meta-Analysis. The international journal of lower extremity wounds. 2016 May 5:1534734616645444.

[21]. Afshari M, Larijani B, Fadayee M, Ghahary A, Pajouhi M, Bastanhagh MH, Baradar-Jalili R, Vassigh AR, Darvishzadeh F. Efficacy of topical epidermal growth factor in healing diabetic foot ulcers

[22]. Brown RL, Breeden MP, Greenhalgh DG. PDGF and TGF- $\alpha$ act synergistically to improve wound healing in the genetically diabetic mouse. Journal of Surgical Research. 1994 Jun 30;56(6):562-70.

[23]. S. P. Bennett, G. D. Griffiths, A. M. Schor1, G. P. LeeseandS. L. Schor. Growth factors in the treatment of diabetic foot ulcers.British Journal of Surgery. 2003 feb; 90(2):133-146

[24]. Cohen IK, Crossland MC, Garrett A, Diegelmann RF. Topical application of epidermal growth factor onto partial-thickness wounds in human volunteers does not enhance reepithelialization. Plast Reconstr Surg. 1995 Aug;96(2):251-4. 